Kızıltaş, Y. ve Kozikoğlu, ì. (2020). İki dilli öğrencilerin okuduğunu anlamada yaşadıkları sorunlar ve çözüm önerileri: Bir durum çalışması. Ana Dili Eğitimi Dergisi, 8(4), 1568-1584.

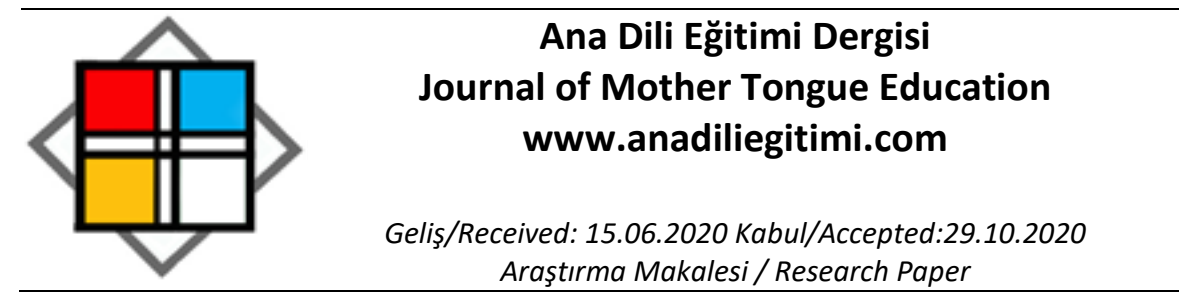

\title{
İki Dilli Öğrencilerin Okuduğunu Anlamada Yaşadıkları Sorunlar ve Çözüm Önerileri: Bir Durum Çalışması*
}

\author{
Yusuf KIZILTAŞ ${ }^{* *}$ \\ ishak KOZIKOĞLU ${ }^{* * *}$
}

\begin{abstract}
Öz
İki dilli olmak günümüzde önemli ve neredeyse kaçınılmaz bir durum olarak dikkat çekmektedir. Bu durum bir avantaj yarattığı gibi çeşitli olumsuz sonuçlar da ortaya çıkarabilmektedir. Özellikle Türkiye'nin belirli bölgelerinde öğrenim gören ilkokul öğrencilerinin iki dilli olmaktan dolayı okuduğunu anlamada sorunlar yaşadıkları bilinmektedir. Bu araştırmanın amacı; iki dilli ilkokul öğrencilerinin okuduğunu anlamada yaşadıkları sorunları tespit etmek ve bu doğrultuda çözüm önerileri geliştirmektir. Araştırmada nitel araştırma yöntemlerinden durum çalışması deseni kullanılmıştır. Araştırmanın çalışma grubunu, Van ili Tuşba ilçesindeki ilkokullarda görev yapan 20 sınıf öğretmeni oluşturmaktadır. Araştırma verileri yarı yapılandırılmış görüşme yolu ile toplanmıştır. Elde edilen verilerin değerlendirilmesinde betimsel analiz tekniği kullanılmıştır. Araştırmanın sonucunda, öğretmen görüşlerine göre iki dilli öğrencilerin dil çatışması yaşamaları ve kelime bilgisinin kısıtlı olmasından dolayı okuduğunu anlamada tek dilli öğrencilere daha çok zorlandıkları ve bu durumun diğer derslerdeki başarıyı etkilediği belirlenmiştir. Öğretmenlerin iki dilli öğrencilerin okuduğunu anlama becerilerini geliştirmek için çeşitli etkinlik ve stratejiler kullandıkları sonucuna ulaşılmıştır. Bu durumda, iki dilli öğrencilerin okuduğunu anlama becerilerini geliştirmek için veli katılımının sağlanması ve program/ders kitaplarının bölge şartları dikkate alınarak öğrenci düzeyine uygun hale getirilmesi önerilebilir.
\end{abstract}

Anahtar Kelimeler: Iki dillilik, okuduğunu anlama, ilkokul öğrencileri, yaşanılan sorunlar

\section{Reading Comprehension Problems of Bilingual Students and Suggestions for Solution: A Case Study}

\begin{abstract}
Being bilingual is an important and almost inevitable situation. This situation creates an advantage as well as can lead to various negative results. Primary school students especially studying in certain regions of Turkey are known to experience reading comprehension problems due to the problem of being bilingual. The purpose of this study is to identify the problems that bilingual primary school students experience in reading comprehension and to develop solutions accordingly. Case study, one of the qualitative research methods, was used in this study. The study group of the study consists of 20 classroom teachers working in the province of Tusba, Van. The research data were collected through semi-structured interview form. In data analysis, descriptive analysis technique was used. As a result of the study, it was determined that bilingual students had more difficulty in reading comprehension due to the language conflict and limited knowledge of vocabulary, and this situation affects their success in other courses. It was concluded that teachers
\end{abstract}

\footnotetext{
* Araştırmanın etik kurul izni: Van Yüzüncü Yıl Üniversitesi Sosyal ve Beşeri Bilimleri Yayın Etik Kurul Başkanlığı, 02/06/2020, 2020/05-03

** Dr. Öğr. Üyesi, Yüzüncü Yıl Üniversitesi, Eğitim Fakültesi, Temel Eğitim Bölümü, Van, Türkiye, ysfkiziltas@gmail.com, ORCID: 0000-0001-9434-4629

*** Doç. Dr. Yüzüncü Yıl Üniversitesi, Eğitim Fakültesi, Eğitim Bilimleri Bölümü, Türkiye, ishakkozikoglu@yyu.edu.tr, ORCID: 0000-0003-3772-4179
} 
use various activities and strategies to develop bilingual students' reading comprehension skills. In this case, it may be suggested to provide parents' participation to improve the comprehension skills of bilingual students and to adapt the program/textbooks to the student level by taking into account the regional conditions.

Keywords: Bilingualism, reading comprehension, primary school students, problems encountered

\section{Giriş}

Okuma, çok yönlü ve üst becerileri içeren önemli bir süreç olarak değerlendirilmektedir. Bu yönüyle günlük hayatın birçok alanında okumanın etki ve izlerinin olduğunu da vurgulamak gerekir. Heckman'a (2006) göre özellikle örgün eğitimde istenen başarıya ulaşmanın ön koşulu okumaya ve okuduğunu anlamaya bağlıdır. Çocukların doğru, akıcı bir şekilde okuması, okuduğunu anlaması ilkokul eğitiminin en önemli amaçlarından biri olarak ifade edilebilir.

Okuma kavramının geniş bir anlam ifade ettiği bilinmektedir. Dolayısıyla okumanın içeriğini, özelliklerini de iyi değerlendirmek ve açıklamak gerekmektedir. Anderson, Hiebert, Scott ve Wilkinson (1985) tarafından yayımlanan "Becoming a Nation of Readers: The Report of the Commission on Reading" isimli rapor incelendiğinde, okumanın arz ettiği önem ve kapsam daha iyi anlaşılmaktadır (Akt..Frankel, Becker, Rowe ve Pearson, 2016). Bu rapora göre okuma beş temel prensip üzerine temellendirilmiştir:

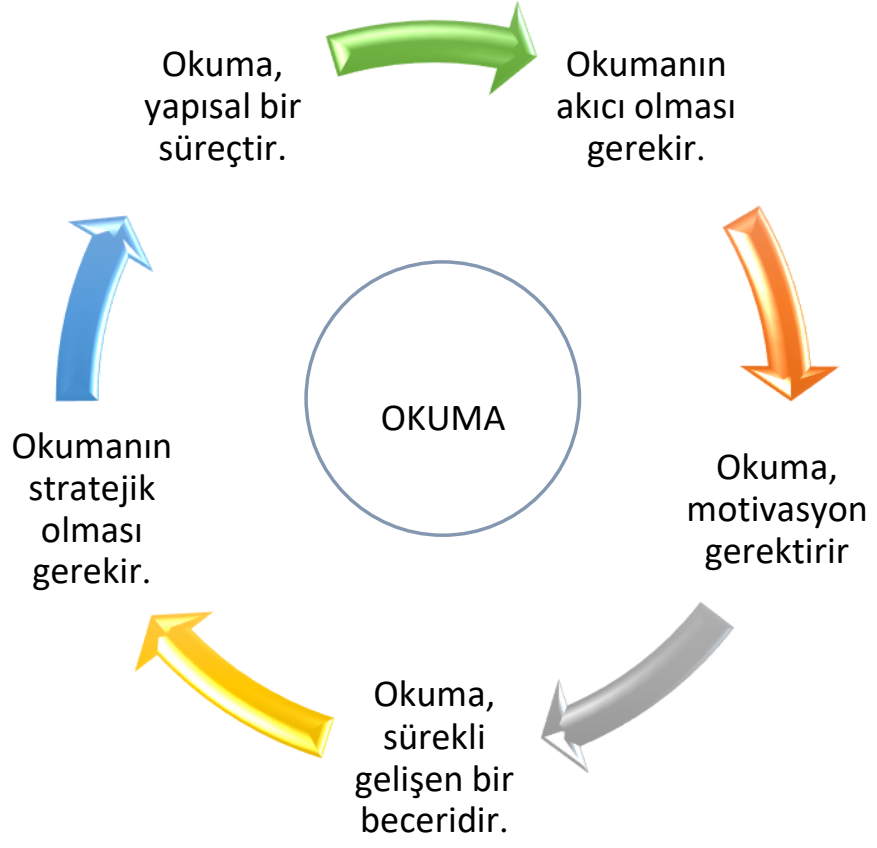

Şekil 1. Okumanın Prensipleri

Şekil 1 incelendiğinde, okumanın çok yönlü bir yapı arz ettiği anlaşılmaktadır. Schoenbach, Greenleaf, Cziko ve Hurwitz (1999) okumanın aynı zamanda karmaşık ve bir problem çözme süreci olduğunu vurgulayarak burada kastedilen akıcı olmanın kod çözmek olarak değerlendirilmemesi gerektiğini ifade etmişlerdir.

Okuma sürecinin dar bir tanıma sığdırılamayacağı görülmektedir. Bu doğrultuda okuma; kitap, gazete, mektup, makale gibi çeşitli metinlerden okuyucunun çeşitli stratejiler kullanarak anlam çıkarmaya çalıştığı, hem düşünme hem de algılama gerektiren, bilinçli/bilinçsiz, interaktif, karmaşık ve zihinsel bir süreç olarak tanımlanmaktadır (Alyousef, 2005; Blachowicz ve Ogle, 2008; Mikulecky, 2011; Nunan, 2003; Pang, Muaka, Bernbardt ve Kamil, 2003; Pourhosein, Gilakjani ve Lahijan, 2016). Okuma, kelime tanıma ve anlama gerektiren bir süreç olup burada ifade edilen anlama; sözcükleri, cümleleri ve metni anlamlandırma sürecidir. Okuduğunu anlamayı gerçekleştirmenin ön koşulu, okuyucunun önceki deneyimlerinden yararlanmasıdır (Pang, Muaka, Bernbardt ve Kamil, 2003). 
Okuduğunu anlama; kelime bilgisi, akıcılık, deneyim, konuya aşina olma gibi çeşitli dilsel ve bilişsel süreçler içeren karmaşık bir süreç olarak değerlendirilmektedir. Bilişsel süreçlerden herhangi birinin eksik olması halinde okuduğunu anlama performansının olumsuz etkileneceği ifade edilmektedir (Abdelaal ve Sase, 2014; Gorjian ve Sayyadian, 2017; Oakhill, Kate ve Carsten, 2015; Spencer ve Wagner, 2018). Okuduğunu anlama; okuyucunun cümleleri anlamasına, cümledeki maddeleri/ifadeleri bilip anlamlandırmasına ve en temelde cümledeki kelimelerin anlamını bilmesine dayanmaktadır. Bu da okumanın hiyerarşik bir düzen içerisinde gerçekleştiğini göstermektedir (Abdelaal ve Sase, 2014).

Okuduğunu anlama, metinde görünürde veya saklı olan anlamı, tahminleri, değerlendirmeleri çeşitli üst bilişsel okuma stratejileri kullanarak bulma veya yapma yeteneği olarak değerlendirilebilir. Okuyucu metni anlamaya başladığında eleştirmeye, analiz etmeye, yorumda bulunmaya, bağlantılar kurmaya ve fikirleri değerlendirmeye başlayacaktır. Anlama gerçekleştiğinde, okuyucu metindeki kelime seviyesinin de ötesine geçmeye yönelik çaba gösterir. Bu yüzdendir ki anlama, okumanın temelidir (Agbo, Kadiri ve Ekwueme, 2019; Ahmadi, Ismail ve Abdullah, 2013; Vellutino, 2003).

Okuduğunu anlamada başarılı olabilmek için, okuyucunun metni anlaması, metinle ilgili bilgi ve deneyime sahip olması gerekir. Bu çerçevede okuduğunu anlamada sahip olunması gereken en önemli bilgi ve deneyimlerden bir tanesi de kelime bilgisidir (Juliana, 2018). Kelime bilgisi de özellikle yeni dil öğrenenlerde, okuduğunu anlama için daha büyük önem arz etmektedir. Fakat yeni dil öğrenen öğrenciler, okuduğunu anlama için gerekli yeterli kelime bilgisine sahip olmamakla birlikte bir metinle karşılaştı̆̆ında yorumda bulunacak yeterli deneyime de sahip değillerdir (Chastain, 1988; Gathercole ve Pickering, 2000; Steensel, Oostdam, Gelderen ve Schooten, 2016). Al-Jarrah ve Binti Ismail (2018, s.32) de ana dilinin dışında ikinci bir dil öğrenenlerin metinleri okurken, tek dilli öğrencilere göre (Romly, Rahman, Supie ve Nasharudin, 2018, s.493) ciddi manada anlama problemleri yaşadıklarını belirtmektedirler. Kasim ve Raisha $(2017$, s.309) da aynı şekilde ana dilinin dışında ikinci dil öğrenen $\mathrm{EFL}^{1}$ öğrencilerinin en büyük problemlerinin okuduğunu anlama konusunda yoğunlaştığını belirtmektedir. Özellikle iki dil arasındaki sosyo-kültürel ve dil yapısına ait farklılıkların, kelime bilgisinin, bireyin hep birinci dilde düşünmeye alışmıs olmasının okuma ve okuduğunu anlama konusunda sorunlara yol açtığına dikkat çekmektedir. Kelime bilgisinin ve dil yapılarının iç içe oldukları, dolayısıyla ikinci dilde okuduğunu anlamada da önemli bir etkiye sahip olduğu söylenebilir. Nitekim Şekil 2'de sunulan Gough ve Tunmer'in (1986, Akt. Friesen ve Haigh, 2018, s.3) 'Basit Okuma Modeli' de bu durumu desteklemektedir.
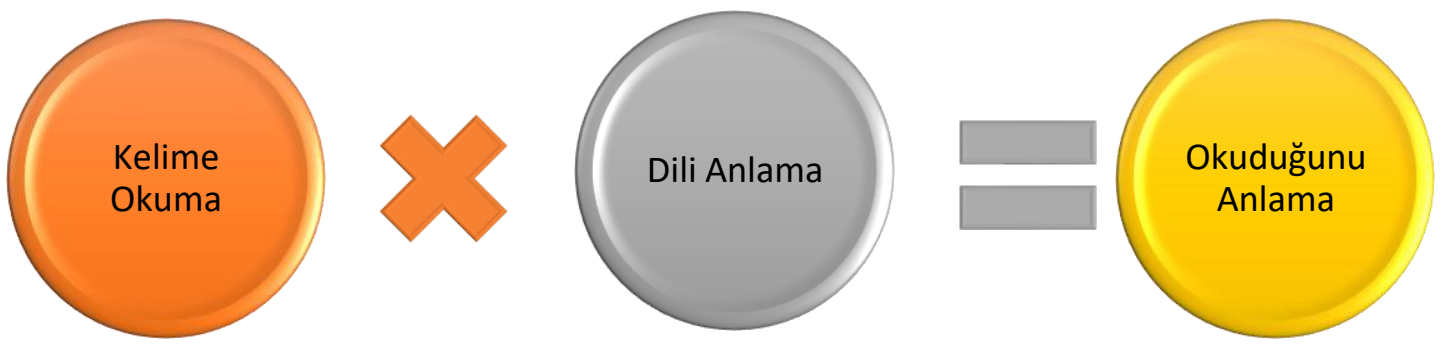

Şekil 2. Basit Okuma Modeli

Bu modele göre özellikle tek dilli ve ana dilinin dışında eğitim gören ya da ikinci dil öğrenen iki dilli öğrencilerde okuduğunu anlama becerisi; kelime okuma bilgisine ve dili anlamasına dayanmaktadır. Ifade edilen bu iki alanda yaşanacak zorluklar iki ve tek dilli öğrencilerde zayıf bir okuyucu olmaya ya da okuduğunu anlamanın yetersiz düzeyde kalmasına yol açabilir.

Ana dili eğitim dilinden farklı iki dilli öğrencilerin okuduğunu anlama konusunda sorunlar yaşadıkları söylenebilir. Bu problemlerin çözüme kavuşturulması ikinci dil öğretiminde başarılı olmak için büyük önem taşımaktadır. Öyle ki 21.yy, ana dili eğitim dilinden farklı öğrencilerin en az ana

\footnotetext{
${ }^{1}$ Ana dili İngilizce olan bir ülkede ikinci dil olarak İngilizceyi öğrenen bireyler
} 
dillerindeki kadar ikinci dilde de yetkin olmalarını gerektirmektedir (Uribe-Enciso, 2015). Bayat (2017) da bu konuya dikkat çekmektedir. Fakat yaşanan problemlerin nedenini daha farklı bir duruma bağlamaktadır. Özellikle Türkiye'de ana dili eğitim dilinden farklı iki dilli öğrencilerin okulda genellikle Türkçe olarak eğitim ve öğretime devam ettiklerini, buna karşın gündelik hayatlarında Türkçeyi çok sık kullanmadıklarını belirtmektedir. Türkiye'de söz konusu iki dilli öğrencilere yönelik bir program olmadığı için de bu problemlerin ortaya çıktığını belirtmektedir.

Alanyazın incelendiğinde, ana dili eğitim dilinden farklı iki dilli öğrencilerin okuduğunu anlama konusunda yaşadıkları sorunları ele alan çalışmaların bulunduğu söylenebilir. Bayat (2017) yaptığı araştırmasında, iki dilli öğrencilerin okuduğunu anlama becerilerini incelemiştir. Tek dilli öğrencilerle iki dilli öğrencilerin okuduğunu anlama becerilerinde tek dilli öğrenciler lehine ciddi bir fark olduğunu belirlemiştir. Kasim ve Raisha (2017) EFL öğrencilerinin okuduğunu anlama konusunda yaşadıkları problemler üzerinde çalışmışlardır. Bu durumun altında yatan en önemli nedeni dilbilimine bağlamışlardır. Öğrencilerin özellikle alışık olmadıkları kelimelerle karşılaştıklarında zorluklar yaşadığını belirtmişlerdir. Bunun da kelime bilgisinin azlığı ile ilgili olduğu söylenebilir. Shehu (2015) da benzer şekilde ana dili dışında ikinci bir dil öğrenen EFL öğrencilerinin okuduğunu anlama konusunda yüzleştikleri sorunlar üzerinde çalışmıştır. Kelime bilgi düzeyinin az olması, karşılaşılan kelimelerin çabuk unutulması, okuma faaliyetlerinin istenen düzeyde olmaması, metin yapılarının uygun olmamasının okuduğunu anlama konusunda yaşanan sorunların nedenleri olarak ifade edilmiştir. Uribe-Enciso (2015) da EFL öğrencilerinin çeşitli okuma stratejileri desteği ile okuduğunu anlama performanslarının geliştirilmesi üzerinde çalışmışır. Friesen ve Haigh (2018) de benzer şekilde ana dillerinin dışında ikinci dil öğrenen öğrencilerin okuduğunu anlama becerisinin nasıl geliştirileceği konusunda çalışmışlardır. Bu çalışma sonuçları, iki dilli öğrencilerin tek dilli öğrencilere kıyasla okuduğunu anlama konusunda daha dezavantajı olduklarını ortaya koymaktadır. Türkiye'de ana dili farklı iki dilli öğrencilerin okuduğunu anlama konusunda yaşadıkları sorunları, bu sorunlara yönelik çözüm önerileri sunan araştırmaların oldukça sınırlı olduğu dikkat çekmektedir. Dolayısıyla ülkemizde öğrenim gören iki dilli öğrencilerin okuduğunu anlamada yaşadıkları sorunları belirlemeye yönelik çalışmalara ihtiyaç olduğu görülmektedir. Bu çıkış noktasından hareketle, bu araştırmada öğretmen görüşlerine göre iki dilli öğrencilerin okuduğunu anlama konusunda yaşadıkları sorunlar ve çözüm önerileri üzerinde durulmuştur. Bu amaç kapsamında aşağıdaki sorulara yanıt aranmıştır:

1. İki dilli öğrencilerin okuduğunu anlamada yaşadıkları sorunlar nelerdir?

2. İki dilli öğrencilerin okuduğunu anlamada yaşadıkları sorunların diğer dersler üzerindeki yansımaları nelerdir?

3. Öğretmenler okuduğunu anlamaya yönelik iki dilli öğrenciler için ne tür etkinlikler yapmaktadır?

4. Öğretmenlerin iki dilli öğrencilerin okuduğunu anlamada yaşadıkları sorunların üstesinden gelmek için çözüm önerileri nelerdir?

\section{Araştırmanın Modeli}

\section{Yöntem}

Bu çalışmada, nitel araştırma desenlerinden durum çalışması (case study) deseni kullanılımışır. Durum çalışmalarında bir veya birden çok birey, olay ya da durum ile bu durumu etkileyen veya bu durumdan etkilenen değişkenler üzerine yoğunlaşılmaktadır (Yıldırım ve Şimşek, 2011). Bu çalışmada, iki dilli öğrencilerin okuduğunu anlamada yaşadıkları sorunlar ve durumun diğer derslerdeki başarıları üzerindeki yansımaları inceleneceğinden durum çalışması deseninin araştırmanın amacına uygun olduğu düşünülmektedir.

\section{Çalışma grubu}

Araştırmanın çalışma grubu, Van ili Tuşba ilçesinde görev yapan 20 öğretmenden oluşmaktadır. Çalışma grubunun belirlenmesinde amaçlı örnekleme yöntemlerinden ölçüt örnekleme kullanılmıştır. Ölçüt örneklemede, araştırmanın amacına uygun olacak şekilde belirli ölçüt(ler) belirlenir ve belirlenen ölçütü/ölçütleri karşılayan birey, olay veya durumlar çalışma grubuna alınır (Büyüköztürk, Kılıç-Çakmak, 
Akgün, Karadeniz ve Demirel, 2016). Bu çalışmada, öğretmenler için sınıfında tek dilli ve çift dilli öğrencilerin bulunması ölçüt olarak belirlenmiş ve bu ölçütü karşılayan sınıf öğretmenleri çalışma grubuna alınmıştır. Çalışma grubundaki öğretmenlerin kişisel özellikleri Tablo 1'de sunulmuştur.

Tablo 1.

Çalışma grubundaki öğretmenlerin kişisel özellikleri

\begin{tabular}{lll}
\hline Özellik & Kategori & Sayı (N) \\
\hline Cinsiyet & Kadın & 9 \\
& Erkek & 11 \\
\hline Mesleki Deneyim & $1-5$ yıl & 5 \\
& $6-10$ yıl & 9 \\
& 11 yıl ve üzeri & 6 \\
& Toplam & 20 \\
\hline
\end{tabular}

Tablo 1'de sunulduğu gibi, çalışma grubundaki öğretmenlerin 9'u kadın, 11'i erkektir. Öğretmenlerin 5'i 1-5 yıl arası, 9'u 6-10 yıl arası, 6'sı ise 11 yıl ve üzeri mesleki deneyime sahiptir.

\section{Veri Toplama Araçları}

Araştırma verileri, araştırmacılar tarafından geliştirilen yarı-yapılandırılmış görüşme formu kullanılarak elde edilmiştir. Görüşme formu beş sorudan ve bu sorularla ilgili sonda sorulardan oluşmaktadır. Görüşme formunda; öğretmenlerin iki dilli öğrencilerin okuduğunu anlamada yaşadıkları sorunlara, okuduğunu anlamada yaşanılan sorunların diğer dersler üzerindeki yansımalarına, okuduğunu anlamaya yönelik öğretmenlerin yaptıkları etkinliklere ve çözüm önerilerine yönelik açık uçlu sorulara yer verilmiştir. Görüşme formundaki soruları dil ve içerik yönünden incelemek üzere dört uzmandan (Sınıf öğretmenliği, Türkçe öğretmenliği ve Eğitim Bilimleri alanlarından) görüş alınmıştır. Uzman görüşü sonucunda, bir soru görüşme formundan çıkarılmış ve diğer sorularda uzmanların dönütleri doğrultunda dil ve içerik bakımından gerekli düzeltmeler yapılarak görüşme formuna son hali verilmiştir.

\section{İşlem / Verilerin Toplanması}

Görüşmeler, 2019-2020 eğitim-öğretim yılının bahar döneminde gerçekleştirilmiştir. 15 öğretmenle görüşmeler telefonla yapılırken, beş öğretmenle öğretmenlerin talebi dikkate alınarak görüşleri yazııı olarak alınmıştır. Öğretmenlerle yapılan görüşmeler ortalama 20 dakika sürmüştür.

\section{Verilerin Analizi}

Araştırma verileri betimsel analiz tekniği kullanılarak analiz edilmiştir. Betimsel analiz tekniğinde; araştırma verileri üzerinden temalar belirlenir, veriler belirlenen temalara göre düzenlenerek betimlenir ve yorumlanır (Yıldırım ve Şimşek, 2011). Bu araştırmada, görüşme soruları ve veriler çerçevesinde temalar belirlenmiş ve araştırma verileri belirlenen temalar altında düzenlenerek betimlenmiştir.

\section{Geçerlik ve Güvenirlik}

Araştırmada dış güvenirliği sağlamaya yönelik araştırmanın amacı ve alt problemleri, çalışma grubu, veri toplama aracı, verilerin toplanması ve veri analizi gibi aşamalara ilişkin ayrıntılı açıklamalara yer verilmiştir. İç güvenirliği sağlamaya yönelik veriler araştırmacılar tarafından ayrı ayrı kodlanmış, Miles ve Huberman'ın (1994) formülüne (Güvenirlik=Görüş birliği/(görüş birliği+görüş ayrılı̆̆ı)) göre iki farklı kodlayıcı arasındaki uyum yüzdesi hesaplanmış ve \%96 uyum bulunmuştur. Bu durumda, yapılan kodlamaların yeterli düzeyde güvenilir olduğuna karar verilmiştir (Miles ve Huberman, 1994). Araştırmada iç ve dış geçerliği sağlamaya yönelik ise betimlemeler doğrudan alıntılarla desteklenmiştir. 


\section{Etik Kurulu İzni}

Yapılan bu çalışmada "Yükseköğretim Kurumları Bilimsel Araştırma ve Yayın Etiği Yönergesi" kapsamında uyulması belirtilen tüm kurallara uyulmuştur. Yönergenin ikinci bölümü olan "Bilimsel Araştırma ve Yayın Etiğine Aykırı Eylemler" başlığı altında belirtilen eylemlerden hiçbiri gerçekleştirilmemiştir.

Kurul adı =Van Yüzüncü Yıl Üniversitesi Sosyal ve Beşeri Bilimleri Yayın Etik Kurul Başkanlığı Karar tarihi $=02 / 06 / 2020$

Belge sayı numarası $=2020 / 05-03$

\section{Bulgular}

Öğretmenlerle yapılan görüşmelerden elde edilen veriler; “iki dilli öğrencilerin okuduğunu anlamada yaşadıkları sorunlar", "okuduğunu anlamada yaşanılan sorunların diğer dersler üzerindeki yansımaları", "okuduğunu anlamaya yönelik yapılan etkinlikler" ve "çözüm önerileri" olmak üzere dört tema altında gruplandırılmıştır. Araştırma verileri belirlenen temalara göre sırasıyla betimlenerek sunulmuştur.

\section{İki Dilli Öğrencilerin Okuduğunu Anlamada Yaşadıkları Sorunlar}

Öğretmenlere "iki dilli ve tek dilli öğrencilerin okuduğunu anlama becerilerine ilişkin görüşleriniz nelerdir? iki dili öğrencilerin okuduğunu anlamada sorun yaşadığını düşünüyor musunuz? Sizce bu durumun nedenleri nelerdir?" sorusu yöneltilmiştir. Öğretmenlerin neredeyse tamamı $(n=18)$ iki dilli öğrencilerin tek dilli öğrencilere kıyasla okuduğunu anlamada daha çok zorlandıklarını ifade etmişlerdir. i̇ki öğretmen ise iki dilli ile tek dilli öğrenciler arasında okuduğunu anlama bakımından bir fark olmadığını belirtmişlerdir. Bu duruma ilişkin öğretmen görüşlerinden ön plana çıkanlara aşağıda yer verilmiştir.

"Ciddi bir fark var. İki dilli öğrencilerin normalde daha avantajlı olması gerekirken maalesef bizim ülkemizde bu tam tersinedir." (Ö8)

"Önemli bir fark var. Tek dilli öğrenciler bu konuda daha başarılı. Oysa iki dilli öğrenci Türkçe ile tanıştığında bocalamaya başlıyor. Hatta sesleri, harfleri karıştırıyor."(Ö10)

"Önemli bir fark var, bunu söylemek gerekir. Okuduğunu anlama konusunda ciddi sorunlar var."

Yukarıda öğretmen görüşlerinde de vurgulandığı üzere, öğretmenlerin çoğu $(n=18)$ iki dilli öğrencilerin okuduklarını algılayamadığı için anlamada zorlandıklarını belirtmişlerdir. Bazı öğretmenler ise iki dilli öğrencilerin dil bilgisi yanlışlarını daha çok yaptıklarını $(n=3)$ veya kavram karmaşası yaşadıklarını $(n=2)$ ifade etmişlerdir. Öğretmenler iki dilli öğrencilerin okuduğunu anlamada yaşadıkları sorunların çeşitli nedenleri olduğuna dikkat çekmişlerdir. Öğretmenlerin neredeyse tamamı iki dilli öğrencilerin okuduğunu anlamada yaşadıkları sorunların nedenlerini dil çatışması yaşamaları $(n=18)$ ve kelime bilgilerinin kısıtı olması ( $n=17)$ olarak belirtmişlerdir. Bu duruma ilişkin öğretmen görüşlerinden ön plana çıkanlara aşağıda yer verilmiştir.

"Kelime hazinesinin yeterli gelmemiş olması ciddi bir nedendir. Öğrenci metinde karşılaştığı bir kelime karşısında gerçekten anlama konusunda sorun yaşayınca oraya takılıyor, bu da metnin bütününü anlamamasına neden oluyor. Tabi diğer önemli bir neden de çocuğun önceki yaşantısıdır ki bunu dil bağlamında diyorum. Çocuğun her yaşantısı önceki dile yani Kürtçeye göre şekillenmiştir. Bu durum Türkçe ile karşılaştığında bir çatışma yaratabiliyor." (Ö7)

"iki dilli çocuklar evet bir zorluk yaşıyorlar. Çünkü dil çatışması yaşıyorlar. Mesela eve gidince başka bir dil yani Kürtçe; okula geldiklerinde başka bir dil yani Türkçe ile karşılaşıyorlar. Bu bir zorluk nedenidir. Çocuk zaten Türkçeyi okulda öğreniyor. Ama çocuk her ne kadar okulda Türkçe konuşuyor olsa da Türkçe kelimelerin tam olarak hangi anlama karşllık geldiğini bilemiyor. Mesela anne kavramını okuyor, anne diyor. Ama anne kelimesinin gerçekte tam olarak hangi anlama geldiğini idrak edemiyor." (Ö2)

Yukarıda öğretmen görüşlerinde de vurgulandığı üzere, öğretmenlerin çoğu iki dilli öğrencilerin evde konuşulan dil ile okulda konuşulan dilin farklı olması, okulda konuşulan dilin evde desteklenmemesi ve öğrencilerin kelime dağarcığı kısıtlı olduğu için okuma metinlerindeki kelimelerin anlamını bilmemeleri 
gibi nedenlerden dolayı okuduğunu anlamada zorlandıklarını ifade etmişlerdir. Ayrıca bazı öğretmenler, iki dilli öğrencilerin okuduğunu anlamada yaşadıkları sorunların nedenlerini iki dilli öğrencilerin kendi ana dillerinde düşünmeleri $(n=5)$, kitap okuma alışkanlıklarının olmaması $(n=5)$, okul öncesi eğitim almamaları $(n=2)$, ailelerin ilgisizliği $(n=2)$, imkânların kısıtlı olması $(n=1)$ olarak ifade etmişlerdir. Bu duruma ilişkin öğretmen görüşlerinden ön plana çıkanlara aşağıda yer verilmiştir.

"Bu çevrede, bölgede kitap okuma alışkanlığı yok. Bu da çocuğun hep aynı kelimeleri kullanmasına neden oluyor, kelime dağarcığı da gelişmiyor. Ayrıca, en önemlisi okul öncesi eğitim çok kötü düzeyde, daha da önemlisi bu sorunu çözme konusunda çok iyi eğitim verilmiyor." (Ö9)

"Kürtçe düşünme diye bir durum var. Kürtçe düşünüyor, Türkçe anlatmaya çalışıyor, ama anlatınca da Türkçesinden bu durum anlaşıımıyor." (Ö4)

"iki dilli öğrenciler zaten bu anlamda gerideler. Bir de aileler ilgisiz maalesef. Evde okuma etkinlikleri yapılmadığı için, aile desteği olmadığı için çocuk öğrendiğini evde pekiştiremiyor." (Ö20)

Yukarıda öğretmen görüşlerinde de vurgulandığı üzere, öğretmenler iki dilli öğrencilerin okuduklarını anlamaya çalışırken öncelikle anadillerinde düşünüp Türkçe'ye çeviri yaptıkları, okuma alışkanlarının olmadığı ve aile desteği olmadığı için okuduğunu anlamada daha çok zorlandıklarına dikkat çekmişlerdir.

\section{Okuduğunu Anlamada Yaşanılan Sorunların Diğer Dersler Üzerindeki Yansımaları}

Öğretmenlere "iki dilli öğrencilerin okuduğunu anlamada yaşadıkları sorunların diğer derslere yansımasının olduğunu düşünüyor musunuz? Sizce bu durum diğer dersleri nasıl etkilemektedir?" sorusu yöneltilmiştir. Öğretmenlerin tamamı $(n=20)$ iki dilli öğrencilerin okuduğunu anlamada yaşadıkları sorunların diğer dersler üzerinde olumsuz yansımalarının olduğunu ifade etmişlerdir. Öğretmenlerin çoğu ( $n=14)$ bu durumun öğrencilerin tüm derslerdeki başarısını etkilediğini belirtirken öğretmenlerin bir kısmı özellikle bazı dersler üzerinde daha çok etkili olduğunu savunmuşlardır. Bu duruma ilişkin öğretmen görüşlerinden ön plana çıkanlara aşağıda yer verilmiştir.

"Diğer derslere kesinlikle etkisi vardır. En bariz örneği Matematikte çok iyi olan bir Suriyeli öğrencim vardı. Dört işlemde problemleri işlediğim zaman, öğrenci problemi okuduğunda anlamıyordu. Fakat problemi ben anlatarak okuduğum zaman, kalem kullanmadan zihinden hızlıca çözebiliyordu." (Ö14)

"Evet diğer derslere etki ediyor. Mesela okuduğunu anlayamayınca Matematik dersindeki problemleri de yapamıyor. Çünkü gerçekten yönergeleri anlamıyor okuduğu zaman. Hayat Bilgisi dersine de yansıyor bu durum. Yani şöyle diyeyim; bir işlemi verince yapıyor. Mesela bir toplama, çıkarma işlemi verince hemen yapıyorlar. Bu konuda gerçekten başarılılar ama söz konusu problem olunca, işin içine okuduğunu anlama girince aslında cevabını bildiği soruyu yapamıyor." (Ö12)

"Okuduğunu anlama sorunu diğer derslere de etki ediyor. Mesela Fen Bilgisi dersinde okuduğunu anlama çok etkileyici bir role sahip. Bizim öğrencilerimiz İngilizce dersinde çok başarısız. Aslında İngilizce dersinde başarısız tablonun nedeni Türkçe konusunda hala okuduğunu anlama sorunu çözüme kavuşturmamış olmamızdır. Çocuk Türkçeyi anlayamıyorken ondan İngilizceyi anlamasını bekliyoruz." (Ö11)

"Hayat Bilgisi dersinde bu sorun bariz görülüyor. Çünkü okuduğunu anlamıyorlar." (Ö9)

"Matematik, Fen Bilimleri, Hayat Bilgisi gibi derslerde intiyaç duyulan ifade, soru ve yönergeleri anlayamamak ve cevaplayamamak sıkıntı yaşatıyor." (Ö13)

Yukarıda öğretmen görüşlerinde de vurgulandığı üzere, öğretmenler iki dilli öğrencilerin okuduğunu anlamada yaşadıkları sorunların öğrencilerin birçok dersteki başarısını veya performansını etkilediğini dile getirmişlerdir. Öğretmenlerin çoğunun özellikle Matematik $(n=16)$ ve Hayat Bilgisi $(n=15)$ derslerinde öğrencilerin verilen problem durumlarını, yönergeleri anlamlandıramadıkları için zorlandıklarını belirttikleri görülmektedir. Ayrıca, bazı öğretmenler iki dilli öğrencilerin okuduğunu anlamada yaşadıkları sorunların Fen Bilimleri $(n=6)$ ve İngilizce $(n=2)$ derslerine olumsuz yansımalarının olduğunu ifade etmişlerdir. 


\section{Okuduğunu Anlamaya Yönelik Yapılan Etkinlikler}

Öğretmenlere "iki dilli öğrencilerin okuduğunu anlama becerilerini geliştirmek için okuma sürecinde hangi etkinlikleri yapıyorsunuz? Okuduğunu anlama stratejilerini kullanıyor musunuz? Varsa hangi stratejileri kullanıyorsunuz?" sorusu yöneltilmiştir. Öğretmenlerin, iki dilli öğrencilerin okuduğunu anlama becerilerini geliştirmek için çeşitli etkinlik ve stratejiler kullandıkları ortaya çıkmıştır. Öğretmenlerin en çok sırasıyla okuduğunu anlama stratejilerini (özet çıkarma, altını çizme, soru-cevap, ana fikri söyleme, vb.) kullandıkları $(n=8)$, tekrarlı okumalar yaptırdıkları $(n=8)$, görsel materyaller kullandıkları $(n=7)$, basit düzeyde kısa okuma metinleri kullandıkları $(n=7)$, serbest okuma etkinlikleri yaptıkları $(n=6)$, anadilden örnekler verdikleri $(n=6)$ görülmektedir. Bu duruma ilişkin öğretmen görüşlerinden ön plana çıkanlara aşağıda yer verilmiştir.

"Sürekli kitap okutuyorum. Çünkü bu bölgede bu büyük bir sorun. Yapılacak en önemli ve maalesef tek alternatif budur. Her gün bir saatimizi okumaya ayırıyoruz." (Ö19)

"Bu konuda tekrarlı okumalar yaptırıyorum. Bu arada ders kitaplarındaki metinler çok uzun dolayısıyla metinleri kesme, kısaltma yoluna gidiyorum. Gerekirse cümle cümle olarak okuma yapıyoruz. Kitap okumalarında ağır gidiyorum ve sindire sindire. Hikâye kitaplarından istifade ediyorum." (Ö6)

"ilkokulda metinler bol resimli olduğu için resimlerden faydalanıyorum, örneğin resimleri gösterip bu metinde ne anlatılıyor gibi sorular soruyorum. Okuma sırasında gereken yerlerde canlandırmalar veya açıklamalar yapıyorum. Kendilerine ilginç gelen yerleri not alabileceklerini söylüyorum. Okuma bittikten sonra özet olarak anlatmalarını istiyorum, metne yönelik sorular soruyorum, metnin konusunu ve ana fikrini bulduruyorum." (Ö15)

"Okuma etkinliklerinde daha iyi çağrışım yapması ve akılda kalıcı olması için öğrencinin anlamını bilmediği kelimelerde anadilinden örnekler veriyorum." (Ö6)

Ayrıca, bazı öğretmenler iki dilli öğrencilerin okuduğunu anlama becerilerini geliştirmek için drama/oyun/canlandırma yaptıklarını $(n=4)$, video/film/animasyon gibi materyaller kullandıklarını $(n=4)$, şarkı/şiir/bilmece gibi etkinlikler yaptıklarını $(n=3)$, sesli okumalar yaptırdıklarını $(n=2)$, hikâye kitapları kullandıklarını $(n=2)$, 5N1K tekniğini kullandıklarını $(n=2)$, zengin uyarıılar sunduklarını $(n=1)$ ifade etmişlerdir. Bu duruma ilişkin öğretmen görüşlerinden ön plana çıkanlara aşağıda yer verilmiştir.

“iki dilli öğrencilerde okuduğunu anlama sorunu yavaş okuma işe başlıyor önce. 5N1K tekniğini kullanıyorum okuduklarını anlamalarını değerlendirmede. Ayrıca çeşitli görsel materyaller de geliştiriyorum. Anlamaları için kelime kelime, cümle cümle gidiyorum. Çok küçük okuma metinleri vererek okumalarını ve kısa sürede anlamalarını sağlıyorum." (Ö5)

"Video ve drama uygulamalarını kullanıyorum. Okunan bir cümleyi ve metni drama ile canlandırmaya çalışıyoruz. Video ile destekliyoruz." (Ö3)

"Daha önce karşılaşmadığı, duymadığı kelimeleri ve cümleleri görsel etkinlik, video vb. dokümanlarla öğrenmesini ve bunların kendi dilindeki karşılıkları ile eşleştirmesini sağlıyorum. Okuma-yazma öğrendikten sonra basit, seviyeye göre bir ya da iki kıtalık şiir, bilmece, tekerleme vb. ile pekiştiriyorum. Öğrenci seviye ve yaşına uygun eğitici çizgi film ve animasyonlarla öğrenme ve pekiştirmenin güçlenmesini sağlıyorum." (Ö13)

\section{Çözüm Önerileri}

Öğretmenlere "iki dilli öğrencilerin okuduğunu anlamada yaşadıkları sorunların üstesinden gelmek için çözüm önerileriniz nelerdir? Sizce neler yapılmalıdır?" sorusu yöneltilmiştir. Öğretmenler, iki dilli öğrencilerin okuduğunu anlama becerilerini geliştirmek için çeşitli önerilerde bulunmuşlardır. Öğretmenlerin en çok sırasıyla veli desteği/katıımının sağlanması ( $n=12)$, program/ders kitaplarının bölge şartlarına göre öğrenci düzeyine uygun hale getirilmesi $(n=10)$, öğretmenlerin eğitilmesi $(n=10)$, velilerin bilinçlendirilmesine yönelik eğitim/seminerlerin düzenlenmesi $(n=8)$ gibi önerilerde bulundukları görülmektedir. Bu duruma ilişkin öğretmen önerilerinden ön plana çıkanlara aşağıda yer verilmiştir.

"Ders kitaplarının basitleştirilmesi olmazsa olmazdır. Basitleştirilen ders kitaplarının görsellerle de desteklenmesi gerekmektedir. Aşırı yazılı metinler var. Bu sıkıcıdır. Neredeyse 6-7 sayfayı bulan metinler var. Bu çok zorluyor iki dilli öğrencileri. Biz bunları basitleştirmek zorunda kalıyoruz. Ders 
kitaplarında ciddi bir sorun var. Tabi burada veli ilgisizliğinden de bahsetmek gerekir. Velilerin katılımı sağlanmalıdır bu sorunun üstesinden gelmek için. Öğretmenlere bakanlık tarafından yaşanan bu sorunlara ve sorunların çözümüne yönelik seminerler verilmelidir. Öğretmenlerin de bu konuda kendini geliştirmeleri lazım. Bu arada batıdan gelen ve Kürtçe bilmeyen öğretmenlerin bu sorunların üstesinden gelmesine yönelik seminerler almaları da oldukça önemlidir." (Ö3)

"Okuma metinleri çok uzun. Bu durum değerlendirilerek kısaltılabilir. Ben şu an dördüncü sınıfları okutuyorum ama orda bile metinler hem soyut hem çok uzun. Velilerin bu konuda sürece dâhil olması lazım. Maalesef öğrenciye değer ve önem vermiyorlar. Bir umursamazlık var velilerde." (Ö12) "Velilere yönelik eğitim programları düzenlenmeli, okuduğunu anlama becerilerinin gelişmesine yönelik uygulamalardan bahsedilmeli, çocuklarla doğru iletişim kurmaları gerektiği belirtilmeli, iletişim kurulan dilin daha çok iki dilli çocuklar için en çok problem yaşadığı dilden yana tercih edilmesi gerektiği bildirilmeli. Veliler bu hususta seminerler ve eğitimlerle bilinçlendirilmeli." (Ö1) "Velilere büyük görev düşüyor. Özverili davranmaları gerekir. Çocukları evde çalıştırmaları lazım dil gelişimi açısından. Ders kitaplarının ciddi manada basitleştirilmesi için çalışmalar yapılmalı. En azından bu bölgenin çocuklarına dağıtılacak ders kitapları farklı olmalıdır. Yani dilsel açıdan dezavantajlı durumda olan öğrencilerin ülkenin diğer bölgelerindeki çocuklarla aynı kitapta eğitim görmeleri bence iki dilli öğrencilerin geride başlamasına neden olmaktadır. Bu bölgeye gelecek öğretmenlere de eğitimler verilebilir bu sorunun üstesinden gelmek adına." (Ö2)

Ayrıca, bazı öğretmenlerin ailede okuma etkinliklerinin yaptırılması $(n=6)$, hikâye vb. okuma etkinliklerinin yapılması $(n=5)$, okul öncesi eğitimin desteklenmesi $(n=4)$, görsellerin kullanılması $(n=2)$, ek okuma materyallerinin kullanılması $(n=2)$, okuma stratejilerinin kullanılması $(n=1)$ gibi önerilerde bulunduğu belirlenmiştir. Bu duruma ilişkin öğretmen önerilerinden ön plana çıkanlara aşağıda yer verilmiştir.

"Okul öncesi eğitim olmazsa olmazdır. Önce bunu belirtmek lazım. Bence $4+4+4$ sistemi yapılmaktansa iki dilli öğrenciler için 1. sınıf hazırlık sınıfı faaliyeti görebilir." (Ö11)

"Hikâye okuma saatlerinin getirilmesi lazım bana göre. Aile içerisinde okuma faaliyetleri yapılmalı ki öğrenci onları model alsın. Bu gerçekten etkili olacaktır." (Ö8)

\section{Tartışma ve Sonuç}

$\mathrm{Bu}$ araştırmada, öğretmenlerin neredeyse tamamının iki dilli öğrencilerin tek dilli öğrencilere kıyasla okuduğunu anlamada daha çok zorlandıklarını düşündükleri sonucuna ulaşıımıştır. Öğretmenlerin neredeyse tamamının iki dilli öğrencilerin okuduğunu anlamada yaşadıkları sorunların nedenlerini dil çatışması yaşamaları ve kelime bilgilerinin kısıtı olması olarak belirttikleri sonucuna ulaşılmıştır. Ayrıca bazı öğretmenlerin, iki dilli öğrencilerin okuduğunu anlamada yaşadıkları sorunların nedenlerini iki dilli öğrencilerin kendi ana dillerinde düşünmeleri, kitap okuma alışkanlıklarının olmaması, okul öncesi eğitim almamaları, ailelerin ilgisizliği ve sosyoekonomik imkânların kısıtlı olması olarak ifade ettikleri belirlenmiştir. Ayrıca tek dilli öğrencilerin bu anlamda daha başarılı olduğu ortaya çıkmıştır. Bu araştırma sonuçları, iki dilli olmanın yarattığı avantaj iki dilli öğrencilerin okuduklarını anlamada daha başarılı olmalarında (Yeganeh ve Malekzadeh, 2015) etkili olmadığını göstermektedir. Açıklanan nedenlerden dolayı bu durum Türkiye'de dezavantajı bir durum haline gelmektedir.

Genel anlamda iki dilli öğrencilerin okuduğunu anlama konusunda daha düşük seviyede kaldıkları ve bu konuda tek dilli öğrencilere göre başarısız oldukları birçok araştırma sonucu ile tutarlılık göstermektedir. Bu çerçevede Jalalipour, Majdinasab, Khedri ve Chadorian (2017) İran'daki iki dilli öğrenciler üzerinde yaptıkları araştırmalarından çıkan sonuca göre iki dilli öğrencilerin ailelerinin genel anlamda eğitim düzeylerinin düşük olduklarına bunun da ailelerin çocuklarına okuduğunu anlama bağlamında sağlayacakları katkı ve ilgi üzerinde belirleyici olduğuna dikkat çekmektedirler. Bu yüzden de iki dilli öğrencilerin okuduğunu anlama konusunda daha başarısız bir performans gösterdikleri ifade edilmektedir. Ailelerin ilgisiz kalmalarının diğer bir nedeni ise genellikle iki dilli öğrencilerin kalabalık aile yapılarını sahip olması şeklinde belirtilmiştir. Söz konusu aileler çoğunlukla beş veya daha fazla çocuklardan oluşmaktadır. Ayrıca iki dilli öğrencilerin tek dilli akranlarına göre ikinci dile daha az maruz kalmalarının; kelime kapasitesi, cümle anlama, fonolojik farkındalık konusunda daha zayıf kalmalarına yol açtığı belirtilmektedir. Dincer, Özaslan ve Kavasoğlu (2003) tarafından yapılan araştırmaya göre, 
Türkiye'de yaşayan iki dilli öğrencilerin ailelerinin de genellikle kalabalık bir yapıya sahip olduğu ortaya çıkmıştır. Aynı şekilde iki dilli öğrenci ailelerinin sosyo-ekonomik düzeylerinin de düşük olduğu belirlenmiştir. İki dilli öğrencilerin aile ortamında veya çevrede Türkçe'ye yeterince maruz kalmamaları, ailelerin ilgisiz kalmaları nihayetinde okuduğunu anlama konusunda ciddi sorunlara yol açmaktadır. ìki dilli öğrencilerin okuduğunu anlama konusunda tek dilli öğrencilere göre daha başarısız oldukları ya da bu öğrencilerin okuduğunu anlama seviyelerinin daha düşük olduğu sonucuna varan başka araştırmaların (Borzou ve Gholamzadeh, 2008; Hutchinson, Whiteley, Smith ve Connors, 2003) da bulunduğunu belirtmek gerekir. Lesaux, Koda, Siegel ve Shanahan (2006) da yaptıkları araştırmaya göre iki dilli öğrencilerin okuduğunu anlama konusunda daha başarısız olmalarını iki faktör altında toplanması gerektiğini belirtmektedirler. Birinci faktör iki dilli öğrencilerin ailelerinin sosyo-ekonomik düzeyi, ikinci faktör ise kelime bilgisi, okuduğunu anlama ile ilgili testler, öğretim materyalleri, kelime okuma becerisi gibi özellikleri içermektedir. Benzer şekilde, Gathercole ve Pickering (2000) de düşük gelirli ailelerden gelen iki dilli çocukların kelime kapasitelerinin daha az olduğunu belirtmektedir. Kelime kapasitesinin sınırlı olmasının da okuduğunu anlama üzerinde önemli bir etkiye sahip olduğu bilinmektedir. İki dilli öğrencilerin okuduğunu anlamaları üzerinde olumsuz bir etki yaratan en önemli kavramlardan bir tanesi de dil çatışmasıdır. Alanyazında dil şoku olarak da ifade edilen bu kavramın kültür şoku ile gerçekleştiği anlaşıımaktadır. Nitekim bu anlamda Gass ve Selinker (2008) da dil çatışması olarak adlandırılan dil şoku ve kültür şokunun ikinci dil edinen öğrencilerde kaçınılmaz bir durum olduğunu ifade etmektedirler. Dil çatışmasının altında yatan en önemli nedenlerin başında öğrencinin ikinci dil edinim sürecinde ilk dil becerisi ile düşünmeye başlamasıdır. Illk dil becerisi doğru bir şekilde ikinci dil öğrenme sürecine aktarılmadığı takdirde ya da iki dilin yapısı ciddi farklılıklar gösterdiğinde dil çatışması kaçınılmaz hale gelmektedir. Ortaya çıkan bu sonuç da iki dilli öğrencilerin okuduklarını anlamaları üzerinde olumsuz bir etki yaratmaktadır. Zhao (2019) da dil karmaşası yaşayan ve ikinci dil edinen öğrencilerin bu anlamda negatif bir transfer içerisine girdiğine dikkat çekmektedir. Bu da hedef dilde yani Türkçe öğretiminde, okumada başarıyı olumsuz anlamda etkileyebilir. Öte yandan iki dilli olmanın aslında öğrencilerde bir avantaj yarattığını, bu durumun da okuduğunu anlama üzerinde olumlu bir etkisinin olduğu sonucuna varan araştırmalar da bulunmaktadır. Gelderen ve arkadaşlarının (2003) yaptığı çalışmalarından çıkan sonuca bakıldığında, iki dilli öğrencilerin okuduğunu anlama konusunda tek dilli öğrencilere göre daha başarılı olduğu ortaya çıkmıştır. Benzer şekilde Karimi ve Kabiri'nin (2011) çalışmalarından çıkan sonuçlar da iki dilli öğrencilerin okuduğunu anlama konusunda daha iyi olduklarını göstermektedir. Yapılan araştırmalardan çıkan sonuçlara bakıldığında iki dilli olmanın tek dilli öğrencilere göre avantaj yarattığı anlaşılmaktadır.

Yukarıda tartışıldığı üzere, alanyazındaki benzer araştırma sonuçları ve bu araştırma sonuçlarından hareketle, öğretmen görüşlerine göre Türkiye'de öğrenim gören iki dilli öğrencilerin tek dilli öğrencilere kıyasla okuduğunu anlamada daha çok zorlandıklarını söylemek mümkündür. Her ne kadar bunun en önemli nedenleri iki dilli öğrencilerin dil çatışması yaşamaları (evde konuşulan dil ile okulda konuşulan dilin farklı olması, okulda konuşulan dilin evde desteklenmemesi) ve kelime bilgilerinin kısıtlı olması olarak görülse de bu faktörlerle ilişkili olarak iki dilli öğrencilerin kendi ana dillerinde düşünmeleri, kitap okuma alışkanlıklarının olmaması, okul öncesi eğitim almamaları, ailelerin ilgisizliği ve sosyo-ekonomik imkânların kısıtlı olması gibi faktörlerin de etkili olduğu düşünülebilir. Dolayısıyla, iki dilli öğrencilerin hem dil kaynaklı hem de aile ve çevre kaynaklı faktörlerden dolayı okuduğunu anlamada tek dilli öğrencilere göre daha dezavantajlı durumda oldukları söylenebilir.

Sınıf öğretmenlerinin büyük bir çoğunluğunun görüşlerine göre, iki dilli öğrencilerin okuduğunu anlamada yaşadıkları sorunların diğer dersler üzerinde de olumsuz bir etki yarattığı sonucuna ulaşılmıştır. îki dilli öğrencilerin matematik, fen bilimleri ile ilgili derslerde problemleri okuduklarını ama anlayamadıklarını ifade ettikleri belirtilmiştir. Benzer şekilde İngilizce, Hayat Bilgisi derslerinde de öğrencilerin okuduklarını anlamadıkları sonucuna varılmıştır. Okuduğunu anlamanın tüm dersler üzerinde etkili olduğu anlaşılmaktadır. Dolayısıyla diğer derslerde de okuduğunu anlamayı geliştirmeye dönük etkinliklerin yapılması ve çeşitli stratejilerin kullanılması büyük önem taşımaktadır. Nitekim Akbaşlı, Şahin ve Yaykıran (2016) yaptıkları araştırmalarında, okuduğunu anlamanın matematik ve fen bilgisi dersleri üzerinde oldukça etkili olduğu sonucuna varmışlardır. Benzer şekilde Thürmann, Vollmer ve Pieper'e 
(2010) göre, matematik dersinde öğrencilerin zorlanmalarında okuduğunu anlama seviyelerinin zayıf olması etkili olmaktadır. Vilenius-Tuohimaa, Aunola ve Nurmia (2008) da öğrencilerin matematik kelime problemlerini çözme becerisi ile öğrencilerin metinleri anlama becerileri arasında önemli bir ilişki olduğunu belirtmektedir. İlkokul öğrencileri üzerinde yaptıkları araştırmaya göre okuduğunu anlama becerisi iyi olan öğrencilerin matematik dersindeki problemleri çözme konusunda da başarılı olduğu sonucuna varmışlardır. Matematik derslerinde yapılan okumaların teknik bir okuma olduğunu ayrıca belirtmektedirler. Hansel ve Pondiscio (2016) ise okuduğunu anlama ile diğer dersler arasındaki ilişkinin farklı bir boyutuna dikkat çekmektedir. Buna göre eğer ilköğretim okullarında sosyal bilgiler, fen bilgisi ve sanat derslerinde okuma ile ilgili etkinliklere daha fazla zaman ayrılırsa, çocukların okuduklarını anlama seviyelerinde de bir gelişme sağlanır. Yıldız (2013) da benzer şekilde yaptığı araştırmasından çıkan sonuca göre fen, sosyal bilgiler ve matematik derslerinde öğrencilerin başarılı olabilmeleri için akıcı okuma becerilerinin iyi olmasının dışında okuduklarının anlamalarının da gerekli ve önemli olduğunu belirtmektedir. Demirel ve Epçaçan (2012) da öğrencilerin, okuma parçalarını anlamaya yönelik etkinlikler sonunda kavramayı pekiştirici sorular oluşturmaya ve yanıtlamaya yönlendirilmesi gerektiğini belirtmektedirler. Öğrencilerde oluşması hedeflenen anlamlı öğrenme için Türkçe dersinin dışında fen ve teknoloji öğretimi, hayat bilgisi ve sosyal bilgiler öğretimi gibi derslerde de öğrencileri konuya ilişkin özetleme, gruplama ve örgütleme yapmaya teşvik edilmesini ifade ederek okuduğunu anlamanın ne kadar önemli olduğuna dikkat çekmişlerdir. Okuduğunu anlamanın matematik, fen bilgisi, tarih gibi dersler üzerinde ve nihayetinde öğrencinin akademik başarısında önemli bir etki yarattığını belirten araştırmaların da bulunduğunu belirtmek gerekir (Cimmiyotti, 2013; Grimm, 2008; Whitten, Labby ve Sullivan, 2016).

Yukarıda tartışıldığı üzere, alanyazındaki benzer araştırma sonuçları ve bu araştırma sonuçlarından hareketle, öğretmen görüşlerine göre iki dilli öğrencilerin okuduğunu anlamada yaşadıkları sorunların diğer dersler üzerinde de olumsuz yansımalarının olduğu görülmektedir. Dolayısıyla, okuduğunu anlama becerilerinin genelde tüm dersler üzerinde etkili olmakla birlikte özellikle Matematik, Hayat Bilgisi, Fen Bilimleri gibi derslerde sunulan problemleri veya okuma metinlerini öğrenciler anlayamadıkları için başarıyı olumsuz etkilediği söylenebilir.

Sınıf öğretmenlerinin iki dilli öğrencilerin okuduğunu anlama becerilerini geliştirmek için özellikle özet çıkarma, altını çizme, soru-cevap, ana fikri söyleme, tekrarlı okumalar, görsel materyaller kullanma, basit düzeyde kısa okuma metinleri kullanma, serbest okuma, anadilden örnekler verme gibi stratejiler, etkinlikler kullandıkları sonucuna ulaşılmıştır. Bazı öğretmenlerin ise drama/oyun/canlandırma yaptıkları, video/film/ animasyon gibi materyaller kullandıkları, şarkı/şiir/bilmece gibi etkinlikler yaptıkları, sesli okumalar yaptırdıkları, hikâye kitapları kullandıkları, 5N1K tekniğini kullandıkları, zengin uyarıcılar sundukları belirlenmiştir. Ortaya çıkan bu sonuç yapılan bazı araştırma sonuçları ile tutarlılık göstermektedir. Balcı ve Dündar (2017) yaptıkları araştırmalarında ikinci dil öğretiminde; özetleme, yeni kelimeleri kontrol etme, not alma ve sözcük anlamını kestirme stratejilerinin okuduğunu anlama becerilerini olumlu yönde etkilediği sonucuna ulaşmışlardır. Bu çalışmada sınıf öğretmenlerinin iki dilli öğrencilerin okuduklarını anlamalarını geliştirmeye dönük her ne kadar beli başlı okuma stratejilerini kullansalar da yeterli düzeyde stratejiler kullanmadıkları ve bu konuda öğretim materyallerinin neredeyse hiç geliştirilmediği anlaşılmaktadır. Daha ziyade birtakım geleneksel yöntem, teknikler ve stratejiler yolu ile bu sorunların üstesinden gelinmeye çalışıldığı söylenebilir. Öte yandan bazı öğretmenlerin iki dilli öğrencilerin okuduğunu anlama becerilerini geliştirmek için çeşitli etkinlikler yapmaları ve farklı okuma stratejileri işe koşmaları olumlu bir durum olarak değerlendirilebilir.

Özellikle iki dilli öğrencilerin okuduğunu anlama becerilerini geliştirmede etkili ve doğru stratejileri kullanmak oldukça önemlidir. Nitekim Echeverri ve McNulty (2010) iki dilli öğrencilerle yaptıkları araştırmalarda, özellikle etkileşime dayalı okuma faaliyetleri ve okuma stratejilerinin kullanıımasının öğrencilerin okuduklarını anlamaya ciddi katkılar sağladığı sonucuna ulaşmışlardır. Benzer şekilde, Zhang, Gu ve Hu'ya (2008) göre iki dilli öğrencilerin okuma etkinliklerinde anlama stratejilerini kullanmaları, okuma yeteneklerini ve bilişsel kapasiteleri artırarak daha yüksek gelişmişlik seviyesine ulaşmalarını da sağlar. Almaguer ve Esquierdo (2013) ise okuduğunu anlamayı geliştirmede KWL tekniğinin iki dilli öğrencilerin öğrendikleri hakkında düşünmelerine ve önceki bilgilerinin, deneyimlerinin yeni öğrenmelerin inşasında nasıl bir etki yarattığını ortaya çıkarmak açından etkili 
olduğunu belirtmektedir. Ayrıca iki dilli öğrencilerin okuma konusunda yaşadıkları sorunların üstesinden gelmek için etkinliklerin büyük önem taşıdığını vurgulamaktadır. Bunun için de öğretmenlere büyük sorumluluklar düşmektedir. Öğretmenler iki dilli öğrencileri yüksek düzeyde düşünme becerileri gerektiren etkinlikler yaparak ve öğrencileri bu süreçlere dâhil ederek onların bu anlamdaki sorunlarını çözebilirler. Kung (2019) ikinci dil edinen öğrenciler üzerinde yaptıkları araştırmasından çıkan sonuçlara göre özellikle otantik (gerçek) öğretim materyallerin kullanılmasının okuduğunu anlamada önemli katkılar sağladığını belirtmektedirler. Çünkü otantik materyaller iki dilli öğrencilerin gündelik hayatları ile büyük bir yakınlık göstermektedir. Ayrıca öğretmenlerin, iki dilli çocukların etkili okuduğunu anlama stratejilerinden faydalanmaları için öğrencileri teşvik etmenin önemine dikkat çekmektedir. Bunun için de okuma faaliyetlerinden sonra iki dilli öğrencilerin okudukları üzerinde tartışmaları için öğrencilere yeterince zaman verilmesi gerektiğini ifade etmiştir. Okumanın basit bir faaliyet ve ödev olarak görülmemesi bunun yerine düzenli bir alışkanlık haline getirilmesinin de önemli olduğu vurgulanmaktadır. Benzer şekilde Peacock (1997) da geleneksel dil öğretim sürecinde iki dilli öğrenciler için artık gerçek hayatı yansıtmayan ders kitaplarının ve içerisindeki yüzeysel metinlerin çok da anlam ifade etmediğini belirtmektedir. O yüzden iki dilli öğrencilerin okuduklarını anlamaları noktasında gerçek hayatla ilgili metinlerin tercih edilmesi oldukça önemlidir.

Boardman ve Lasser’a (2006) göre görsel materyallerin kullanılması, sağladığı anlaşılır girdi ile iki dilli öğrencilerin önceki bilgilerini harekete geçirmesine olanak sağlayarak anlama hedeflerine ulaşmasına yardımcı olur. Öğretmenler de iki dilli öğrencilerin görsel materyaller üzerinde yaptıkları yorumlardan hareketle öğrencilere zihinsel gelişimleri, yeni karşılaşılan kavramları ve kelimeleri anlamaları, yanlış anlamaları düzeltmek için destek sağlamalıdır. Ayrıca doğrudan ve etkileşime dayalı kelime öğretimine yönelik etkinlikler, soru-cevap teknikleri, okuma-yazmanın iç içe olduğu etkinlikler de öğrencilerin okuduklarını anlamalarını geliştirmelerine katkı sağlar. Memiş (2019) ikinci dil öğrenim süreci boyunca daha fazla kelime gören veya kelimeye maruz kalan öğrenenlerin okuduğunu anlama bakımından daha başarılı olduğunu belirtmektedir. Bu sonucun ortaya çıkmasında, öğrenenlerin dil öğretim setlerinin içerdiği sözcük sayısına bağı olarak daha fazla anlaşılabilir dil girdisi almasının ve buna bağlı olarak dile hâkimiyetlerinin daha iyi olmasının etkili olduğunu belirtmektedir. Bu yüzden sınıflarda uygulanacak okuduğunu anlama etkinliklerinin de ifade edilen özellikleri kapsaması önemlidir. Laurea (2013), öğretmenlere bu süreçte büyük sorumluklar düştüğünü belirtmektedir. İkinci dil edinimi okuma derslerinde kullanılacak materyallerin hazırlanması ve metinlerin değerlendirilmesi kolay bir iş değildir. Elbette dikkate alınması gereken pek çok değişken vardır. Ancak öğretmenler öğrencilerin ihtiyaçlarına odaklanabildikleri ve okuma etkinliklerine verdikleri tepkiyi tahmin edebildikleri sürece, mümkün olan en iyi seçimleri yapmak için her zaman değerli ipuçlarından yararlanmalıdırlar. íki dilli öğrencilerin okuduğunu anlama becerilerini geliştirip onların yetkin okuyucular olmalarını sağlamak için öğretmenler, çeşitli okuma stratejilerini kullanmalı ve öğrencileri de teşvik etmelidir. Bellek stratejileri kullanılarak öğrencilerin okunan metinlerin içeriği ile ilgili hatırladıklarını ifade etmeleri, bunları görselleştirmeleri, diyagramlar oluşturmaları, anahtar kelimeleri kullanarak bir zihinsel örüntü oluşturmaları sağlanabilir. Bilişsel stratejiler kullanmaları mümkündür. Okudukları metinleri anlamaya yönelik özgün testler geliştirilebilir. Bu metinlerde temel düşünceleri bulmaları bunun için de metni tekrar tekrar okumaları ve iyice gözden geçirmeleri sağlanabilir. Ayrıca önemli noktaları not almaları da sağlanabilir. Thiele (2014) de ikinci dil ediniminde okuduğunu anlamayı geliştirmek için öğretmenin sesli okumalar yaparak öğrencileri de bu etkinliğe teşvik etmenin önemini belirtmektedir. Çünkü sesli okumanın okuduğunu anlama becerisini geliştirmede oldukça etkili olduğunu belirtmektedir. Ailelerin ve çocukların okulun başından tüm öğretim yılı boyunca sürekli birlikte okuma faaliyetleri yapmalarının da gerekli ve önemli olduğunu ifade etmektedir. Okuma öncesi yapılacak etkinliklere ve stratejilere önemli zaman verilmelidir. Öğretmenlerin birçoğu okuma öncesi etkinlikleri yapmak yerine doğrudan okuma faaliyetine geçmektedir. Bunu da zamanın azlığına bağlamaktadırlar. Ancak bu konunun önemli olduğu ve öğrencileri okumaya motive edip anlamaya katkı sağladığı unutulmamalıdır. Örneğin, öğrencileri metni izlerken öğretmenler metnin içeriği, resimleri, başlığı ile ilgili dikkat çekici sorular sorabilir. Bunlar okuma öncesi stratejiler olarak değerlendirilebilir (Alyousef, 2006). 
Bu araştırmada öğretmenlerin, iki dilli öğrencilerin okuduğunu anlama becerilerini geliştirmek için en çok sırasıyla veli desteği/katılımının sağlanması, program/ders kitaplarının bölge şartlarına göre öğrenci düzeyine uygun hale getirilmesi, öğretmenlerin eğitilmesi, velilerin bilinçlendirilmesine yönelik eğitim/seminerlerin düzenlenmesi gibi çeşitli önerileri ön plana çıkmaktadır. Araştırmadan elde edilen sonuçlar ve öğretmenlerin önerileri doğrultusunda geliştirilen öneriler aşă̆ıdaki gibi sıralanabilir:

- Türkiye'de eşitliğe dayalı bir eğitim söz konusudur. Türkiye'deki tüm okullara aynı kitapların gönderilmesi eğitimde fırsat ve imkân eşitliğine uygun bir örnektir. Bunun yanında ihtiyaçlara dayalı bir eğitim politikasının da geliştirilmesi büyük önem taşımaktadır. Bu yüzden iki dilli öğrencilerin yaşadıkları bölgelerdeki okullara yönelik daha uygun öğretim programlarının/ders kitaplarının geliştirilmesi önemli bir intiyaçtır. Bu ders kitapları öğrencilerin içinde bulundukları dilsel dezavantajları en aza indirme açısından önemli bir adım olarak değerlendirilebilir.

- íki dilli öğrencilerin okuduğunu anlama konusunda yaşadıkları sorunları gidermeye, en azından azaltmaya yönelik öğretim materyallerinin neredeyse hiç olmadığı anlaşılmaktadır. Bu eksiklik de etkinliklerin çeşitlilik göstermesini engellemektedir. Özgün, ihtiyaçları ve sorunları gidermeye yönelik öğretim materyallerinin geliştirilmesi önerilebilir.

- Ana dili eğitim dilinden farklı iki dilli öğrencilerin okul öncesi eğitim ile birlikte dil karmaşasını ve şokunu daha kolay atlattıkları dikkate alındığında okul öncesi eğitimin zorunlu hale getirilerek okul öncesi eğitimde onlara Türkçe dil eğitimine yönelik etkinliklerin yapılması önerilebilir.

- $\quad$ Iki dilli öğrencilerin yaşadıkları bölgelere atanan ve Kürtçeyi bilmeyen öğretmenlerin de bir karmaşa yaşadıkları bilinmektedir. Dolayısıyla bu bölgelere atanan öğretmenlerin yaşayacakları bu sorunlara yönelik gerek hizmet öncesinde üniversiteler gerekse de hizmet içi eğitim süreçlerinde Milli Eğitim Bakanlığı desteği ile bir eğitim almaları oldukça önemlidir.

- İki dilli öğrencilerin yaşadıkları sorunlarda ailelerinden yeterince destek alamamaları da etkili olmaktadır. Okulda ve evde farklı diller kullanan iki dilli öğrencilerin bu karmaşadan kurtulabilmeleri için ailelerin evde, mahallede Türkçeyi destekleyecek bir çaba içerisinde olmaları gerekmektedir. Aile katılımı noktasında bakanlık düzeyinde sonuçları, etkililiği takip edilecek ve yüzeysel olmayacak doğru projelerin geliştirilmesi ve velilerin bilinçlendirilmesine yönelik eğitim/seminerlerin düzenlenmesi önerilebilir.

- Bu çalışma Van ilindeki belirli sayıdaki sınıf öğretmenleriyle ve veri toplama aracı olarak görüşme formuyla sınırlıdır. Farklı illerde, veli/okul yöneticileri gibi farklı örneklemlerle konuyu farklı paydaşların görüşleriyle ele alan çalışmalar yürütülebilir. Ayrıca, gözlem gibi veri toplama araçları kullanılarak iki dilli öğrencilerin okuduğunu anlamada yaşadıkları sorunlar daha kapsamlı incelenebilir.

\section{Kaynaklar}

Abdelaal, N. M., \& Sase, A. S. (2014). Relationship between prior knowledge and reading comprehension. Advances in Language and Literary Studies, 5(6), 125-131.

Agbo, I. I., Kadiri, G. C., \& Ekwueme, J. (2019). Investigating the impediments to reading comprehension in junior secondary Schools: Evidence from JSSII students in Nsukka Metropolis. Advances in Language and Literary Studies, 10(2), 143-151.

Ahmadi, M. R., Ismail, H. N., \& Abdullah, M. K. (2013). The importance of metacognitive reading strategy awareness in reading comprehension. English Language Teaching, 6(10), 235-244.

Akbaşlı, S., Şahin, M., \& Yaykıran, Z. (2016). The effect of reading comprehension on the performance in science and mathematics. Journal of Education and Practice, 7(16), 108-121.

Al-Jarrah, H., \& Binti Ismail, N. S. (2018). Reading comprehension difficulties among EFL learners in higher learning institutions. International Journal of English Linguistics, 8(7), 32-41.

Almaguer, I., \& Esquierdo, J. J. (2013). Cultivating bilingual learners' language arts knowledge: A framework for successful teaching. International Journal of Instruction , 6(2), 3-18.

Alyouse, H. S. (2006). Teaching reading comprehension to ESL/EFL learners . Journal of Language and Learning, 5(1), 63-73. 
Alyousef, H. S. (2005). Teaching reading comprehension to ESL/EFL learners. The Reading Matrix, 5(2), 143-154.

Balcı, A., \& Dündar, S. A. (2017). Okuma stratejileri öğretiminin Türkçeyi yabancı dil olarak öğrenen öğrencilerde okuduğunu anlama becerisine etkisi. Ana Dili Eğitimi Dergisi, 5(2), 258-270.

Bayat, S. (2017). Reading comprehension skills of bilingual students in Turkey. European Journal of Education Studies, 3(6), 72-93.

Blachowicz, C., \& Ogle, D. (2008). Reading comprehension. New York, NY: The Guilford Press.

Borzou, S., \& Gholamzadeh, Z. (2008). Study of reading comprehension \& accuracy skills in monolingual \& bilingual (Arab-Fars) students at grade 2 of elementary school in Ahvaz. Ahvaz: Ahvaz Jundishapoor Tıp Bilimleri Üniversitesi.

Büyüköztürk, Ş., Kıllıç-Çakmak, E., Akgün, Ö.E., Karadeniz, Ş., \& Demirel, F. (2016). Bilimsel araştırma yöntemleri. Ankara: Pegem Akademi Yayıncılık.

Chastain, K. (1988). Developing second language skills:Theory and practice (3rd Ed). San Diego: Harcourt Brace Jovanovich.

Cimmiyotti, C. (2013). Impact of reading ability on academic performance at the primary level. California: Dominician University of California.

Demirel, Ö., \& Epçaçan, C. (2012). Okuduğunu anlama stratejilerinin bilişsel ve duyuşsal öğrenme ürünlerine etkisi. Kalem Eğitim ve Insan Bilimleri Dergisi, 2(1), 71-106 .

Dincer, B., Özaslan, M., \& Kavasoğlu, T. (2003). Illerin, bölgelerin sosyo-ekonomik gelişmişlik sıralaması araştırması. Ankara: T.C. Başbakanlık Devlet Planlama Teşkilatı.

Echeverri, L., \& McNulty, M. (2010). Reading strategies to develop higher thinking skills for reading comprehension. Profile, 12(1), 107-123.

Frankel, K. K., Becker, B. L., C, Rowe, M. W., \& Pearson, P. D. (2016). From “What is Reading?" to What is Literacy? Journal of Education, 196(3), 7-17.

Friesen, D., \& Haigh, C. (2018). How and why strategy instruction can improve second language reading comprehension: A review. The Reading Matrix: An International Online Journal, 18(1), 1-18.

Gass, S. M., \& Selinker, L. (2008). Second language acquisition.An introductory course.Third edition. New York ve London: Taylor \& Francis Group.

Gathercole, S. E., \& Pickering, S. J. (2000). Working memory deficits in children with low achievement in the national curriculum at seven years of age. British Journal of Educational Psychology, 70, 177-194.

Gathercole, S. E., \& Pickering, S. J. (2000). Working memory deficits in children with low achievement in the national curriculum at seven years of age. British Journal of Educational Psychology, 177194.

Gorjian, B., \& Sayyadian, M. (2017). A comparative study on bilinguals and monolingual learner reading comprehension. Journal of Applied Linguistics and Language Learning, 3(1), 9-16.

Grimm, K. (2008). Longitudinal associations between reading and mathematics achievement. Developmental Neuropsychology, 33(3), 419-420.

Hagena, M., Leiss, D., \& Schwippert, K. (2017). Using reading strategy training to foster students' Mathematical modelling competencies: Results of a quasi-experimental control trial. EURASIA Journal of Mathematics Science and Technology Education, 13(7b), 4057 -4085.

Hansel, L., \& Pondiscio, R. (2016). ESSA creates an opportunity and an obligation to help every child become a strong reader. 05 01, 2020 tarihinde Knowledge Matters: http://knowledgematterscampaign.org/wp-content/uploads/2016/05/ESSA-brief.pdf adresinden alındı

Heckman, J. J. (2006). Skill formation and the economics of investing in disadvantaged children. Science, 312, 1900-1902.

Hutchinson, J. M., Whiteley, H. E., Smith, C. D., \& Connors, L. (2003). The developmental progression of comprehension-related skills in children learning EAL. Journal of Research in Reading, 26, 19-32. 
Jalalipour, M., Majdinasab, F., Khedri, H., \& Chadorian, B. (2017). A comparison of reading accuracy and reading comprehension in bilingual Arabic/Farsi-speaking and monolingual Farsi-speaking elementary students in the fifth grade. Journal of Rehabilitation Sciences and Research, 4, 97101.

Juliana. (2019). The comparative impacts of using lexical glossing and inferencing strategies on students' reading comprehension. Advances in Language and Literary Studies, 9(1), 1-4.

Karimi, A., \& Kabiri, M. (2003). Comparing bilingual and monolingual students' reading comprehension; According to PIRLS 2006 results:In abstract book of bilingual and education. Challenges, Perspectives, and Solutions Conference. Iran: Research Institute for Education.

Khusniyah, N., \& Lustyantie, N. (2017). Improving English reading comprehension ability through Survey Questions, Read, Record, Recite, Review strategy (SQ4R). English Language Teaching, 10(12), 202-211.

Kung, F. W. (2019). Teaching second language reading comprehension: the effects of classroom materials and reading strategy use. Innovation in Language Learning and Teaching, 13(1), 93104.

Lasser, A., \& Boardman, C. J. (2006). Using strategy instruction to promote reading comprehension and content learning. C. P. Proctor, A. Boardman, \& E. H. Hiebert içinde, Teaching emergent bilingual students: Flexible approaches in an era of new standards (s. 99-118). New York: Guilford Publications.

Laurea, T. D. (2013). Learning how to read in English as a foreign language: issues in Italian secondary school teaching and the role of strategy instruction. Padova: Università degli Studi di Padova.

Lesaux, N. K., Koda, K., Siegel, L. S., \& Shanahan, T. (2006). Development of literacy. D. August, T. Shanahan, \& (Edt) içinde, Developing literacy in second-language learners (s. 75-122). Mahway, NJ: Erlbaum.

Memiş, M. R. (2019). Türkçeyi ikinci dil Olarak öğrenenlerin okuduğunu anlama yeterliklerinin eş değerliği. Ondokuz Mayıs Üniversitesi Eğitim Fakültesi Dergisi, 38(1), 253-265.

Mikulecky, B. C. (2011). A short course in teaching reading: Practical technique for building reading powe. United States: Pearson Longman.

Miles, M. B., \& Huberman, A. M. (1994). Qualitative data analysis. USA: Sage Publications Inc.

Nunan, D. (2003). Language teaching methodology. London: Prentice Hall International.

Oakhill, J., Kate, C., \& Carsten, E. (2015). Understanding and teaching reading comprehension a handbook. London\&New York: Routledge.

Pang, E. S., Muaka, A., Bernhardt, E. B., \& Kamil, M. L. (2003). Task-based language teaching. New York, NY: Cambridge University Press.

Peacock, M. (1997). The effect of authentic materials on the motivation of EFL learners. ELT Journal, 51, 144-156.

Pourhoseingilakjani, A., \& Lahijan, L. B. (2016). How can students improve their reading comprehension skill? Journal of Studies in Education, 6(2), 229-240.

Raisha, U., \& Kasim, S. (2017). EFL students' reading comprehension problems: Linguistic and nonlinguistic complexities. English Education Journal (EEJ), 8(3), 308-321.

Romly, R., Rahman, S. A., Supie, H. S., \& Nasharudin, S. N. (2018). Difficulties encountered by low proficiency ESL students in reading online academic texts. International Journal of Academic Research in Business and Social Sciences, 8(2), 490-501.

Schoenbach, R., Greenleaf, C., Cziko, C., \& Hurwitz, L. (1999). Reading for understanding: A guide to improving reading in middle and high school clasrooms. San Francisco: Jossey-Bass.

Shehu, I. (2015). Reading comprehension problems encountered by foreign language students, case study: Albania, Croatia . Academic Journal of Interdisciplinary Studies, 4(1), 91-96.

Spencer, M., \& Wagner, R. K. (2018). The comprehension problems of children with poor reading comprehension despite adequate. Review of Educational Research, 88(3), 366-400.

Steensel, R. V., Oostdam, R., Gelderen, A. V., \& Schooten, E. V. (2016). The role of word decoding, vocabulary knowledge and meta-cognitive knowledge in monolingual and bilingual low- 
achieving adolescents' reading comprehension. Journal of Research in Reading, 39(3), 312329.

Thiele, J. (2014). Link between oral reading and comprehension for second language learners'. PAU's Academic Journal, 3, 85-92.

Thürmann, E., Vollmer, H., \& Pieper, I. (2010). Language(s) of schooling: focusing on vulnerable learners. 05 01, 2020 tarihinde https://rm.coe.int/16805a1caf adresinden alındı

Uribe-Enciso, O. (2015). Improving EFL students' performance in reading comprehension through explicit instruction in strategies. Rastros Rostros, 17(31), 37-52.

Van Gelderen, A., Schoonen, R., de Glopper, K., Hulstijn, J., Snellings, P., Simis, A., et al. (2003). Roles of linguistic knowledge metacognitive knowledge and processing speed in L3, L2 and L1 reading comprehension. The International Journal of Bilingualism, 7(1), 7-25.

Vellutino, F. R. (2003). Individual differences as sources of variability in reading comprehension in elementary school children, Rethinking reading comprehension (pp. 51-81). New York, NY: Guilford.

Vilenius-Tuohimaa, P., Aunola, K., \& Nurmi, J. (2008). The association between mathematical word problems and reading comprehension. Educational Psychology, 409-426.

Whitten, C., Labby, S. .., \& Sullivan, S. L. (2016). The impact of pleasure reading on academic success. The Journal of Multidisciplinary Graduate Research, 2(4), 48-64.

Yeganeh, M. T., \& Malekzadeh, P. (2015). The effect of bilingualism on the developing of English reading skill. Procedia - Social and Behavioral Sciences, 192, 803-810.

Yıldııı, A., \& Şimşek, H. (2011). Sosyal bilimlerde nitel araştırma yöntemleri. Ankara: Seçkin Yayıncılık.

Yıldız, M. (2013). Okuma motivasyonu, akıcı okuma ve okuduğunu anlamanın beşinci sınıf öğrencilerinin akadamik başarılarındaki rolü. Turkish Studies, 8(4), 1461-1478.

Zhang, L. J., Gu, P. Y., \& Hu, G. (2008). A cognitive perspective on Singaporean primary school pupils' use of reading strategies in learning to read in English. British Journal of Educational Psychology, 78(2), 245-271.

Zhao, Y. (2019). Negative transfer of mother tongue in English. Creative Education, 940-946.

\section{Introduction}

\section{Extended Abstract}

Being bilingual is an important and almost inevitable situation. This situation creates an advantage as well as can lead to various negative results. Primary school students especially studying in certain regions of Turkey are known to experience reading comprehension problems due to the problem of being bilingual.

It can be said that bilingual students whose mother tongue is different from the language of education have problems in reading comprehension. Resolving these problems is crucial for success in second language teaching. In fact, the 21st century requires students whose mother tongue is different from the language of education to be proficient in the second language as well as in their mother tongue (Uribe-Enciso, 2015). Bayat (2017) also draws attention to this issue. But it links the cause of the problems to a different situation. Especially bilingual students from different schools in Turkey generally continue education in Turkish language, while they do not use Turkish very often in everyday life. He indicates that these problems also arise because there is not a program for bilingual students in Turkey.

There is quite limited number of studies in Turkey which analyze reading comprehension problems of bilingual students and suggest solutions to these problems. Therefore, it is seen that there is a need for studies aimed at identifying the problems that bilingual students in Turkey experience in reading comprehension. The purpose of this study is to identify the problems that bilingual primary school students experience in reading comprehension and to develop solutions accordingly. For this purpose, the following questions are addressed in this study:

1. What are the problems that bilingual students experience in reading comprehension? 
2. What are the implications of the problems that bilingual students experience in reading comprehension on other subjects?

3. What kind of activities do teachers do for bilingual students in reading comprehension?

4. What are the solution suggestions for teachers to overcome the problems that bilingual students have in reading comprehension?

\section{Method}

Case study, one of the qualitative research methods, was used in this study. The study group of the study consists of 20 classroom teachers working in the province of Tusba, Van. The research data were collected through semi-structured interview form. In data analysis, descriptive analysis technique was used.

\section{Result and Discussion}

As a result of the study, it was determined that bilingual students had more difficulty in reading comprehension due to the language conflict and limited knowledge of vocabulary, and this situation affects their success in other courses. It was concluded that teachers use various activities and strategies to develop bilingual students' reading comprehension skills. In this study, teachers presented various suggestions such as providing parent support/participation, making the program/textbooks suitable for the student level according to the regional conditions, educating teachers, organizing trainings/ seminars for raising awareness of the parents in order to improve the comprehension skills of bilingual students. Based on the results obtained from this study and the suggestions of the teachers, some suggestions can be listed as follows:

- The education is based on equality in Turkey. Preparation of the same books to all schools in Turkey is an appropriate example of equality for educational opportunity and possibility. In addition, further development of a training policy based on needs is of great importance. For this reason, it is an important need to develop more appropriate curriculum/textbooks for schools in the regions where bilingual students live. These textbooks can be considered as an important step in minimizing linguistic disadvantages of students.

- It is understood that there are almost no teaching materials aimed at eliminating, at least reducing, the problems that bilingual students experience in reading comprehension. Original instructional materials to address needs and problems of bilingual students need to be developed.

- Considering that a bilingual student whose mother tongue is different from the language of education, preschool education gives an opportunity to more easily overcome with language confusion and shock, it is also important to carry out activities for Turkish language education in preschool education by making them compulsory.

- It is known that teachers who do not speak Kurdish, who are assigned to the regions where bilingual students live, also experience confusion. Therefore, it is very important for the teachers appointed to these regions to receive an education for these problems with the support of the Ministry of National Education both in universities and in-service training processes.

- Bilingual students' inability to get enough support from their families is also effective in their problems. Bilingual students who use different languages at school and at home need to be in an effort to support Turkish at home and in the neighborhood to avoid this confusion. At the point of family involvement, it is of great importance to develop effective projects.

- This study is limited to a certain number of classroom teachers in Van province and interview form as a data collection tool. Studies can be carried out in different provinces, with different samples by taking the views of different stakeholders such as parents/ school administrators. In addition, the problems that bilingual students experience in reading comprehension can be examined more comprehensively by using data collection tools such as observation. 